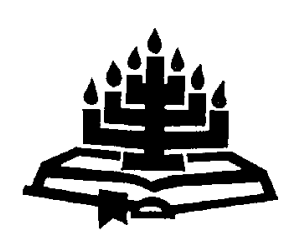

\title{
'n Teologies-etiese perspektief op die beskerming van sosio-ekonomiese regte
}

\author{
H.M. Zwemstra \& J.M. Vorster \\ Skool vir Kerkwetenskappe \\ Noordwes-Universiteit \\ Potchefstroomkampus \\ POTCHEFSTROOM \\ E-pos: 11328843@puknet.puk.ac.za \\ kwsjmv@puknet.puk.ac.za
}

\begin{abstract}
A theological-ethical perspective on the protection of socioeconomic rights

In the human rights discourse the question is no longer asked whether human rights must be protected by a constitution, but rather which human rights must be protected by a constitution. The contemporary question is specifically pointed at the issue whether socio-economic rights must be protected by a constitution and to what extent. In this article socio-economic rights and their protection are evaluated from a theological-ethical perspective. This approach includes the investigation of certain Biblical themes and parts of Scripture from the Old and New Testament. The findings of this investigation indicate that socioeconomic rights are very important human rights that should be protected as effectively as possible.
\end{abstract}

\section{Opsomming}

'n Teologies-etiese perspektief op die beskerming van sosioekonomiese regte

In die menseregtediskoers word nie meer gevra óf menseregte deur 'n grondwet beskerm moet word nie - dit gaan deesdae eerder oor watter menseregte deur 'n grondwet beskerm moet word. Die groot vraag is of sosio-ekonomiese regte deel moet uitmaak van 'n grondwet en indien wel, in watter mate. In hierdie artikel word sosio-ekonomiese regte en die beskerming daarvan teologies-eties beoordeel. Hierdie benaderingswyse sluit in dat bepaalde Bybelse temas en Skrifgedeeltes uit die Ou en Nuwe Testament ondersoek word. Die resultate van hierdie ondersoek dui daarop dat sosio-ekonomiese regte baie 
belangrike menseregte is wat so effektief moontlik beskerm moet word.

\section{Inleiding}

Die beskerming van menseregte in beginsel is in 'n groot mate ' $n$ uitgemaakte saak in Suid-Afrika. Vanuit 'n teologies-etiese perspektief het verskeie navorsers oortuigend aangetoon dat menseregte en die beskerming daarvan prinsipieel gefundeer kan word (vgl. Du Toit, 1991; Greidanus, 1984; Van Wyk, 1987; Vorster, 2001). In 'n menseregtedebat word nie meer gevra óf menseregte deur 'n grondwet beskerm moet word nie - dit gaan deesdae eerder oor watter menseregte deur 'n grondwet beskerm moet word. Die groot vraag is of sosio-ekonomiese regte (tweedegenerasieregte) deur 'n grondwet beskerm moet word.

Hierdie artikel wil daarom die beskerming van sosio-ekonomiese regte vanuit 'n teologies-etiese perspektief navors. By die prinsipiële evaluering van sosio-ekonomiese regte en die beskerming daarvan is dit belangrik om te weet wat sosio-ekonomiese regte is. Om dié rede sal daar aan die begin van hierdie artikel 'n kort beskrywing van sosio-ekonomiese regte en die historiese ontwikkeling daarvan gegee word. Daarna sal oorgegaan word om die beskerming van sosio-ekonomiese regte prinsipieel, dit wil sê in die lig van die Skrif, te beoordeel.

By die prinsipiële beoordeling van sosio-ekonomiese regte en die beskerming daarvan sal bepaalde Bybelse beginsels wat lig werp op sosio-ekonomiese regte ondersoek word. Meer spesifieke gegewens uit die Ou en Nuwe Testament wat van toepassing is op sosio-ekonomiese regte sal ook ondersoek word. Hieruit sal dan 'n samevatting en gevolgtrekking gemaak word oor sosio-ekonomiese regte en die beskerming daarvan.

\section{Sosio-ekonomiese regte en die historiese ontwikkeling daarvan}

In die menseregtediskoers word drie generasies regte onderskei, naamlik eerste-, tweede- en derdegenerasieregte (Vorster, 2001:2).

Politieke en burgerlike regte staan bekend as eerstegenerasieregte. Hierdie regte sluit in: die reg op gelykheid, vryheid, eiendom, spraak, samekoms en assosiasie. Hierdie tipe regte staan ook bekend as die klassieke liberale regte en het in die agtiende eeu begin ontwikkel. Eerstegenerasieregte word gewoonlik as "negatiewe 
regte" beskou, omdat hulle die staat verhinder om op sekere maniere op te tree, soos byvoorbeeld om te diskrimineer (vgl. De Vos, 1997:69). Davis (1992:480, 481) wys egter op die belangrike feit dat eerstegenerasieregte ook 'n positiewe toepassing kan hê.

Sosio-ekonomiese regte staan bekend as tweedegenerasieregte wat hoofsaaklik in die negentiende eeu begin ontwikkel het. Hierdie regte sluit in: die reg op basiese sosiale en ekonomiese middele soos die reg op werk, onderwys, gesondheidsorg, voedsel, water en behuising. Sodanige regte is noodsaaklik vir die individu se behoorlike inskakeling by, en deelname aan die georganiseerde gemeenskapslewe (De Villiers, 1984:24). Tweedegenerasieregte word gewoonlik as "positiewe regte" regte beskou, omdat hulle meer positiewe aksie vereis as eerstegenerasieregte (vgl. De Vos, 1997: $69)$.

Derdegenerasieregte verwys na die regte wat tans ontwikkel word, byvoorbeeld vroueregte, kinderregte en die regte van minderhede. Net soos tweedegenerasieregte word derdegenerasieregte ook as "positiewe regte" beskou, omdat hulle meer positiewe aksie vereis.

Daar is uiteenlopende menings aangaande die historiese oorsprong van sosio-ekonomiese regte. Volgens Siegel (soos aangehaal deur Boshoff, 1991:447) bestaan daar moontlik 'n verband tussen hedendaagse sosio-ekonomiese regte en sestiende- tot agtiende-eeuse Europese sosiale beskerming. Hy meen dat die moderne staat se sosiale verantwoordelikhede teenoor die burgers herlei kan word tot feodale stelsels vóór die agtiende eeu en dat die oorsprong daarvan reeds tydens die Franse Revolusie gevind kan word. Aan die ander kant is daar skrywers wat van mening is dat moderne sosioekonomiese regte uitsluitlik aan die sosialisme toegeskryf moet word. Navorsing oor sosiale strukture wat in pre-koloniale Afrikagemeenskappe gedoen is, toon egter aan dat hier ook sprake van ekonomiese en sosiale ondersteuning vir die individu deur die breër gemeenskap was. Siegel (soos aangehaal deur Boshoff, 1991:447, 448) vat hierdie siening soos volg saam:

Socio-economic rights have rather deep roots, in addition to being socialist, also feudal, mercantilist, Methodist, utilitarian, radical, conservative, Roman Catholic - and even liberal.

Op 10 Desember 1948 het die Algemene Vergadering van die Verenigde Nasies die Universele Verklaring van Menseregte aanvaar (UN, 1995:153; Vorster, 2000:119). Artikels 22 tot 27 van hierdie Verklaring handel oor sosio-ekonomiese regte. Sodanige regte sluit in die reg op sosiale veiligheid, op werk, op rus en 
ontspanning, asook die reg op 'n voldoende lewenstandaard, op onderwys en op deelname aan die kulturele lewe.

Alhoewel die Universele Verklaring van Menseregte 'n belangrike mylpaal vir internasionale menseregte was, het dit geen bindende gesag gehad nie. Daarom het die Verenigde Nasies se Kommissie vir Menseregte reeds in 1947 voorgestel dat daar saam met die Verklaring 'n multilaterale verdrag oor menseregte moet wees. Dié voorstel het daartoe gelei dat twee menseregte-konvensies tot stand gekom het: een oor sosiale, ekonomiese en kulturele regte, die ander oor burgerlike en politieke regte. Hierdie twee menseregtekonvensies is in 1966 aanvaar en het van krag geword in 1976 (Vorster, 2000:127; Liebenberg, 1995:361; Seleoane, 2001:33, 34; UN, 1995:229). Hierdie konvensies staan bekend as die Internasionale Konvensie oor Ekonomiese, Sosiale en Kulturele Regte en die Internasionale Konvensie oor Burgerlike en Politieke Regte.

Die Universele Verklaring van Menseregte, die twee menseregtekonvensies en ander gebeurtenisse soos die Weense Konferensie oor Menseregte (1993) het daarin geslaag om 'n nuwe etos van menseregte in die internasionale politiek tot stand te bring. Al hoe meer lande in die wêreld het begin om 'n handves van menseregte te aanvaar (Vorster, 2000:128). So 'n aanvaarding van 'n handves van menseregte het gepaardgegaan met 'n debat oor watter menseregte in so 'n handves opgeneem behoort te word. In baie gevalle word die vraag gevra of sosio-ekonomiese regte as fundamentele regte beskerm moet word. Ook in Suid-Afrika word hierdie vraag nog gevra. Daarom gaan die beskerming van sosioekonomiese regte vervolgens prinsipieel geëvalueer word.

\section{Prinsipiële evaluering van sosio-ekonomiese regte}

\subsection{Bybelse beginsels vir sosio-ekonomiese regte}

Verskeie navorsers het reeds 'n prinsipiële evaluering van die breë begrip menseregte gemaak (vgl. Du Toit, 1991; Greidanus, 1984; Van Wyk, 1987; Vorster, 2001). Op grond van die werk van hierdie navorsers is dit duidelik dat menseregte nie op grond van tekste (buite hul verband) afgelees kan word nie. Menseregte word gefundeer in bepaalde Bybelse beginsels (Vorster, 2001:7-8; vgl. ook Du Toit, 1984:63). Een Bybelse beginsel mag ook nie losgemaak word van die geheel van die Bybelse teologie en as 'n norm aangebied word nie. Die Christelike etiek sou in hierdie opsig maklik kon verval in óf biblisisme óf 'n sekularisering van die Bybel - soos 
wat inderdaad gebeur het met talle ander etiese kwessies (Vorster, 2001:7).

Omdat sosio-ekonomiese regte menseregte is, ressorteer hulle onder die breë begrip menseregte. Daarom kan Bybelse beginsels wat gebruik word vir die prinsipiële fundering van menseregte, ook gebruik word vir die prinsipiële fundering van sosio-ekonomiese regte. Hierdie Bybelse beginsels is geregtigheid, verantwoordelikheid, liefde, barmhartigheid en arbeidsaamheid. Daar is nog baie ander Bybelse beginsels wat gebruik kan word vir die prinsipiële fundering van sosio-ekonomiese regte, soos byvoorbeeld waarheid, vryheid en vrede. Vir die doeleindes van hierdie artikel word egter volstaan met eersgenoemde beginsels.

\subsubsection{Geregtigheid}

Die betekenis en implikasies van geregtigheid moet in die Skrif afgelei word van die wyse waarop God se geregtigheid tot openbaring kom. Geregtigheid is naamlik God se wil vir die menslike werklikheid; dit is die maatstaf waaraan alles gemeet moet word. Om oor geregtigheid in die Skrif te praat beteken dus om die terrein van die Godsleer te betree (Du Toit, 1988:53; Du Toit, 1991:444; Vorster, 2002:301). Die hele skepping en die mens se verlossing in Christus was God se wil en welbehae. Omdat God dit gewil het, daarom is dit "reg". "Reg" is wanneer 'n saak, toestand of verhouding is soos God dit bedoel het om te wees (Du Toit, 1988:53; Heyns, 1982:273).

In die algemeen staan geregtigheid in die Skrif vir God se wil vir die menslike werklikheid en die handhawing van daardie wil. Meer spesifiek is geregtigheid egter ook iets wat die mens in sy verhouding met sy medemens toekom. Daarom toon Von Rad (1962:370) tereg aan dat geen ander begrip in die Ou Testament so 'n sentrale betekenis vir al die verhoudinge van menslike lewe het as die begrip geregtigheid nie. Geregtigheid is nie alleen die standaard vir die mens se verhouding met God nie, maar ook vir sy verhouding met sy medemens. In al die verhoudinge waarin die mens staan, kom geregtigheid die mens toe.

Die volgende Bybelgedeeltes wys op die verband tussen God se wil (en dus geregtigheid) en die lot van mense wat uitgelewer is aan sosio-ekonomiese nood: armoede, ellende en verdrukking - Miga 6:8; Jesaja 5:16; 58:14; Amos 5:24; Hosea 4:1-3; Esegiël 16:47-49; Jesaja $61: 1,2$ en die vervulling daarvan in Lukas $4: 21$. Telkens is daar ook sprake van God se toorn oor diegene wat die lot van 
armoede, ellende en verdrukking veroorsaak of kontinueer. Dit kom immers neer op 'n verwerping van God se bepalings.

In die Nuwe Testament is dit duidelik dat Christus se opsoekende liefde telkens ook die armes en veragtes, die ellendiges en lydendes insluit (Luk. 4:21; 6:20 e.v.; 20:25-37; 12:13-21 e.v.; 6:19-31; 7:1-10, $36-40 ; 17: 11-19 ; 19: 1-10 ; 24: 11)$. Ook die res van die Nuwe Testament bevat opdragte wat gerig is op die uitvoering van die liefdesgebod en op mense wat die liefde, sorg en meelewing van die gelowiges nodig het (Gal. 5:22-24; 6:2; 1 Kor. 15:58, ensovoorts).

\subsubsection{Verantwoordelikheid}

Daar is reeds daarop gewys dat God die oorsprong van geregtigheid is en dat geregtigheid iets is wat die mens toekom. Die mens word tot hierdie reg en geregtigheid geroep om die Goddelike reg en geregtigheid te bevestig en te erken in sy eie dade en beslissings. Waar God die objektiewe (of ontiese) pool van geregtigheid is, is die mens die subjektiewe (of etiese) pool van geregtigheid (Du Toit, 1988:56). Die mens is geskape en geroep tot gehoorsaamheid aan God se reg. God vra na die vervulling van sy wil en na die waarmaak van sy reg waarvan die liefdesgebod die diepste motivering is en waarin die mens bygestaan word deur God se Wet. Prakties beteken dit 'n lewe wat volgens God se wil is (Du Toit, 1988:56).

Ten spyte van die sonde bly God getrou aan Homself en aan sy skepsels. Dit word in die Skrif beskryf as sy geregtigheid. Vir die gelowige beteken God se trou verlossing. Sy verlossende geregtigheid impliseer verlossing van onreg en ongeregtigheid in die breedste sin van die woord. "Christus ons Geregtigheid" is die vervulling van die belofte aan Israel dat Sion "deur reg" verlos sal word (Du Toit, 1988:57; Jes. 1:27).

Op dié manier oorwin God se reg en vorm dit die grond van sy herskepping, net soos wat dit ook die grond van sy oorspronklike skepping was. God se herskepping in Christus moet egter nog in sy volheid kom; daarom word die gelowige elke dag geroep tot sedelike beslissings wat daarop dui dat God se reg erken word.

Die feit dat die mens in sy dade en beslissing God se reg moet erken, impliseer dat menseregte en daarom ook sosio-ekonomiese regte, nie bloot iets is wat die mens toekom nie, maar dat dit ook ' $n$ verantwoordelikheid inhou. Regte is soos twee kante van dieselfde muntstuk (vgl. Heyns, 1982:387). 


\subsubsection{Liefde}

Die vervulling van God se reg- en geregtigheidseise verskyn in die Persoon van sy Seun, Jesus Christus. Jesus Christus druk God se wese uit, want God is liefde (vgl. 1 Joh. 4:8,16). Die gelowige word nie aan abstrakte regsbeginsels gebind nie, maar aan Hom, aan sy reg en sy liefde. Daarom dui wettisisme nie alleen op die miskenning van die Wet nie, maar ook op miskenning van die liefde. Die hoogste reg bly dus die reg van die Liefde (Du Toit, 1988:58).

Reeds in die Ou Testament is die liefde die samevatting van die Wet (Deut. 6:4, 5; Lev. 19:18), ook ten opsigte van die vreemdeling (Lev. 19:33-34; Heyns, 1982:226, 229). Christus stel die liefde as die eintlike uitgangspunt van die gelowige se ganse bestaan (Matt. 22:37-39). Hierdie uitgangspunt beteken dat ware geregtigheid sonder God onmoontlik is, maar óók dat die liefde nie anders kan as om instrument van geregtigheid te wees nie (Du Toit, 1991:446); daarom moet politieke, sosiale en ekonomiese handelinge ook daardeur bepaal word.

Hierdie liefde is omvattend omdat dit alle mense insluit, ook die vyand (Matt. 5:32 e.v.; Luk. 10:24 e.v.), maar ook omdat dit alle lewensterreine insluit en uitgaan na alle vorme van nood (Matt. 25:31 e.v.). Die liefde is betrokke by pyn en siekte, honger en armoede, by eensaamheid en verdrukking. Hierdie liefde moet nie net teenoor medegelowiges bewys word nie, maar teenoor alle mense.

Liefde beteken om reg aan ander te laat geskied; daarom is dit 'n gestalte van geregtigheid en daarom streef dit daarna om die Wet van God na te kom (Heyns, 1982:228). Vir die hedendaagse samelewing beteken dit dat die liefde daarna sal streef om regverdige wette sowel as sosiaal-maatskaplike en politieke strukture daar te stel.

Omdat die hoogste reg die reg van die liefde is, moet dit in menseregte ook oor liefde gaan. Dit is elke mens se reg om liefde te ontvang, maar dit is ook sy verantwoordelikheid om liefde te gee. Deur uit te reik na mense wat in sosiale en ekonomiese nood verkeer, word liefde konkreet bewys.

\subsubsection{Barmhartigheid}

'n Ander belangrike gestalte van liefde is barmhartigheid. In die $\mathrm{Ou}$ Testament staan barmhartigheid (raham) in verband met rehem wat "moederskoot" beteken (Harris, 1999:841). Soos 'n ongebore baba 
beskerm en gevoed word, so moet die belange van die naaste in 'n omvattende sin die objek van barmhartigheid wees. Dit beteken dat dié wat in nood verkeer, se lot verander moet word sodat hulle "gebore" kan word tot 'n nuwe en menswaardige bestaan in 'n gemeenskap waarin nood opgehef word. Barmhartigheid beteken dus nie alleen meelewing en medelye wat van die hart uitgaan nie, maar ook daadwerklike ontferming wat wil heelmaak, genees en herstel. Jesus se lewe is self 'n voorbeeld daarvan (Mark. 1:41; 6:34 e.v.; 8:2 e.v.). Hy roep die gelowiges ook op om barmhartigheid aan alle mense te bewys (vgl. Matt. 5:7; Luk. 3:11; 6:36; 10:25-37; Du Toit, 1988:61).

\subsubsection{Arbeidsaamheid}

Die mens is na die beeld van God geskape en daarom moet hy iets van die werksame God in sy lewe weerspieël (Gen. 1:27-28). As beeld van God word die mens geroep om God op aarde te verteenwoordig. Die mens het 'n Goddelik opdrag om die skepping te bewaak en te beheers (Gen. 1:28; Gen. 2:18; Ps. 8) - dit is van die vroegste opdragte wat God aan die mens gegee het. Hierdie opdrag om te werk veronderstel dus 'n reg op arbeid (vgl. Van Wyk, 1991: 257; De Bruyn, 1993:259).

Dit is uit die Skrif duidelik dat arbeidsaamheid belangrik is vir lewensonderhoud. Die Here gee aan die mens 'n opdrag om die tuin (en die wêreld) te bewerk (Gen. 2:15), maar daarmee saam mag hy ook van die vrugte eet en daarvan geniet (Gen. 2:16; Van Wyk, 2001:438). Paulus skryf dat elkeen in sy eie lewensonderhoud moet voorsien (Ef. 4:28; 1 Tess. 4:11) en hy vermaan leeglêers om hulle aandag by hulle werk te bepaal en hulle eie brood te verdien (2 Tess. 3:12). Daarom sê hy ook in 2 Tessalonisense 3:10: "As iemand nie wil werk nie, moet hy ook nie eet nie" (vgl. De Bruyn, 1993:260; Van Wyk, 2001:438,439).

'n Belangrike aspek van arbeidsaamheid is dat dit ook ' $n$ vorm van medemenslikheid is. Die mens werk nie net vir homself nie, maar ook vir sy naaste en veral vir arm mense (vgl. Van Wyk, 2001:439). In Handelinge 20:35 sê Paulus: "Deur my voorbeeld het ek in elke opsig vir julle gewys dat ons hard moet werk sodat ons die armes kan help." Aan die gelowiges in Efese skryf hy: "As iemand 'n dief is, moet hy ophou steel; hy moet deur harde werk op 'n eerbare manier self in sy lewensonderhoud voorsien; dan sal hy iets hê om vir die armes te gee" (Ef. 4:28). Wie sy hand vir sy medemens toehou, en veral vir die arm medemens, steel van die Here. "Wie hom oor 'n arm mens ontferm, gee 'n lening aan die Here" (Spr. 19:17; vgl. Spr. 
28:27). Deur sy arbeid laat ' $n$ mens sosiale geregtigheid geskied en word 'n verantwoordelike samelewing opgebou (vgl. Van Wyk, 2001: 11, 12).

Arbeidsaamheid staan ook in verband met die natuur. Die mens bewerk immers die natuur en omskep dit tot kultuur (Van Wyk, 1988:84-97; vgl. Gen. 1:28). Deur sy arbeid moet die mens die natuur beheers en dit ontplooi en dit nie besoedel en vernietig nie. Besoedeling is nie prinsipieel aanvaarbaar nie en moet afgekeur word. As die mens sy eie werkterrein vernietig, kan hy tog in elk geval nie meer werk nie (vgl. Van Wyk, 2001:440).

Elke mens het daarom sedert die skepping van die wêreld 'n reg op arbeid en alles wat hiermee saamgaan: arbeidsgeleenthede, arbeidsvervulling en arbeidsvreugde (Van Wyk, 1991:257). Werksaam-wees is deel van menswees; wie nie werk nie, tas sy eie menswees aan. Die mens moet egter nie 'n slaaf van arbeid wees nie; daarom het God dit ook so bestem dat elke mens moet rus (Gen. 2:2; Eks. 20:11). Saam met die reg op arbeid is daar dus ook die reg op rus.

Uit die bespreking hierbo is dit duidelik dat arbeid fundamenteel belangrik is vir sosio-ekonomiese regte. Wie verantwoordelik werk, beskerm die natuur, voorsien vir homself en vir ander 'n waardige lewenstandaard, maak gesondheidsorg moontlik, maak opvoeding moontlik, maak kulturele lewe en wetenskaplike vooruitgang moontlik, en verseker dat moeders en kinders spesiale sorg ontvang. Arbeid moet egter nie as 'n absolute voorwaarde vir sosioekonomiese regte beskou word nie. Diegene wat nie kan werk nie, se sosio-ekonomiese regte moet naas arbeid beskerm word, soos dit ook blyk uit die bespreking tot dusver.

\subsection{Gegewens uit die Ou en Nuwe Testament}

Uit die bespreking tot dusver is dit duidelik dat sosio-ekonomiese regte uit bepaalde Bybelse beginsels begrond kan word. Daar is egter meer spesifieke gegewens in die Skrif wat gebruik kan word vir die prinsipiële begronding van sosio-ekonomiese regte en die beskerming daarvan. Uit hierdie spesifieke gegewens sal dit duidelik word hoe die beginsels wat reeds bespreek is, destyds toegepas is. Dié toepassings bied normatiewe modelle of paradigmas wat help in die beoordeling van sosio-ekonomiese regte. 
Spesifiek gegewens in die Skrif ten opsigte van sosio-ekonomiese regte gaan ondersoek word deur te kyk na die Ou Testament en daarna na die Nuwe Testament.

\subsubsection{Gegewens uit die Ou Testament}

\subsubsection{Die sosiale en ekonomiese wette van Israel}

Onder 3.1 is reeds genoem dat menseregte nie uit bepaalde tekste (buite hulle verband) afgelees kan word nie. Daarom moet daarteen gewaak word om sosio-ekonomiese regte direk uit die sosiale en ekonomiese wette van Israel te probeer aflees. Tog verskaf hierdie wette belangrike beginsels vir die prinsipiële begronding van sosioekonomiese regte. Dit is ook belangrik om te onthou dat die OuTestamentiese wette nie op 'n a-historiese wyse lynreg na die hedendaagse samelewing oorgedra kan word nie. Die Israelitiese wette het nie binne 'n historiese vakuum ontstaan nie. Die heilshistoriese lyn loop vanaf Israel na die Kerk as die NuweTestamentiese verbondsvolk en nie vanaf Israel na die moderne staat nie (vgl. Greidanus, 1984:6; Vorster, 2002:306-307).

Hierdie afleiding beteken egter nie dat die sosiale en ekonomiese wette van die Ou Testament (wat spesifiek in die Pentateug voorkom) geen normatiewe waarde vir die mens van vandag het nie. Agter hierdie voorskrifte lê 'n teologiese mensbeskouing en teologiese siening van ideale menseverhoudinge, wat vir die hedendaagse realiteit relevant is. Die relevansie van die OuTestamentiese wette kan gesien word in die wyse waarmee Christus met die Ou-Testamentiese wette omgaan. In Matteus 5:17,18 sê Christus:

Moenie dink dat Ek gekom het om die Wet of die profete ongeldig te maak nie. Ek het nie gekom om hulle ongeldig te maak nie, maar om hulle hulle volle betekenis te laat kry. Dit verseker Ek julle: Die hemel en die aarde sal eerder vergaan as dat een letter of letterstrepie van die Wet sal wegval voordat alles voleindig is.

Christus gee wel 'n nuwe betekenis aan die Ou-Testamentiese wette, maar Hy werk nog steeds met dieselfde Godsleer, mensbeskouing en idee van ideale menseverhoudings as die Pentateug. Die Ou-Testamentiese wette bied nie ewige juridiese norme nie, maar bevat wel belangrike teologiese gegewens vir die verstaan van sosiale en ekonomiese regte. 
Die sosiale en ekonomiese wette van Israel is só saamgestel dat elke lid van die gemeenskap 'n menswaardige bestaan kan voer. Dit is nie die sterkes en onafhanklikes in die samelewing wat sukkel om 'n menswaardige bestaan te maak nie, maar die afhanklikes. Daarom word die afhanklikes op 'n besondere manier beskerm. Die afhanklikes in die samelewing is slawe, armes, weduwees, weeskinders en vreemdelinge. Dit is hierdie afhanklikes se reg op ' $n$ menswaardige bestaan wat op 'n besondere manier beskerm moet word. Die eis tot sosiale geregtigheid teenoor die swakkes en afhanklikes word telkens gefundeer in die aard van God wat omsien na die regte van swakkes (vgl. Eks. 23:6, 7 en Deut. 15:9).

\subsubsection{Die digterlike en wysheidsboeke}

In Psalm 82:3, 4 beveel God:

Julle moet reg laat geskied aan die mens in nood en aan die weeskind, 'n regverdige uitspraak vir die hulpelose en die behoeftige lewer, julle moet die mens in nood en die arme bevry, hulle uit die mag van die goddelose red.

Op grond van hierdie bevel van God is dit duidelik dat die sosioekonomiese regte van hulpeloses en behoeftiges vir Hom belangrik is. Verder is dit duidelik dat sosio-ekonomiese regte nie in die eerste plek my regte is nie, maar my verantwoordelikhede teenoor die regte van ander, veral teenoor die hulpeloses en behoeftiges. Dit is in ooreenstemming met Spreuke 29:7: "'n Regverdige mens is besorg oor die reg van arm mense."

Wanneer Job in Job 29:14 sê dat hy reg en geregtigheid laat geskied het, dan sê hy daarna in vers 15 en 16: "Ek was oë vir die blindes en voete vir die kreupeles, ek was 'n vader vir die armes, ek het selfs onbekendes se regsaak behartig." Op dieselfde manier verbind Job 36:6; Psalm 12:6; 68:6; 72:2; 112:9; 146:7, 9; Spreuke 31:9 en Prediker 5:8 reg en geregtigheid met die handhawing van die sosio-ekonomiese regte van armes, verdruktes, weeskinders, weduwees en vreemdelinge.

\subsubsection{Die profete}

Helberg (1984:7) wys daarop dat Israel as verbondsvolk die ernstige fout gemaak het om vas te haak by hulle identiteit as verbondsvolk, in plaas daarvan om hulle taak, verantwoordelikheid en roeping raak te sien. Hulle het vasgehou aan hulle belydenisse oor God, hulle het hul offerandes gebring, godsdienstige feeste gehou en tot God gebid. Hulle het God egter in 'n geïsoleerde middelpunt geplaas. 
Hulle het Hom nie waarlik gedien as God wat groter is as die erediens nie; God wat oor die alledaagse lewe regeer en omsien na die sosio-ekonomiese regte van mense, en God wat Skepper is van die hele aarde en koning van alle mense is nie.

Die Profete wys daarop dat, ondanks Israel se diens aan God, daar nie reg geskied nie, dat die armes en ander hulpeloses verdruk word. In Jesaja betig God die volk soos volg:

Wat het Ek aan julle baie offers? vra die Here. Ek is sat van die brandoffers van ramme en die vet van voerbeeste; die bloed van bulle en lammers en bokke staan My nie aan nie. As julle kom om voor My te verskyn, wie het julle gevra om my voorhowe te kom vertrap? Moenie langer julle nuttelose offergawes bring nie: Ek het 'n afsku van julle wierookoffers. Nuwemaansfeeste, Sabbatsvierings, die uitroep van feesdae: Ek verdra nie feesviering met onreg saam nie ... Leer om weer goed te doen, sorg dat daar reg geskied, gaan die verdrukker teë. Laat reg geskied aan die weeskinders, behartig die regsake van die weduwees (Jes. 1:11, 12, 13, 17). (Vergelyk ook Jer. 7:4-6; Amos 4:1-4.)

Dit is belangrik om daarop te let dat die uitgangspunt van die Profete se eis om geregtigheid nie die mens en sy sosio-ekonomiese regte is nie, maar God en wat Hom toekom. Geen mens is regverdig voor God nie (Jes. 43:9, 26). Geen mens kan dus by God op sosioekonomiese regte aanspraak maak nie. Teenoor owerhede en ander mense het ' $n$ mens egter sosio-ekonomiese regte. Wie arm en verdruk is, het aanspraak daarop om sy sosio-ekonomiese regte te bekom, om "geregverdig" te wees (Jes. 50:8). 'n Mens kan dus sê dat mense sosio-ekonomiese regte van God ontvang waarop hulle hulle teenoor ander kan beroep. Dit is egter belangrik dat by die Profete se uitsprake, net soos by die voorskrifte van die Tien Gebooie, die stelwyse nie só is dat dit vir mense sê wat hulle sosioekonomiese regte is nie. Die Profete roep nie die verontregtes op om op hulle sosio-ekonomiese regte te staan nie. God se eis konsentreer op 'n mens se plig en roeping, dit wil sê op jou plig en roeping teenoor ander mense en hulle sosio-ekonomiese regte. Die Skrif waarsku teen 'n gesindheid wat daarop ingestel is om jou sosio-ekonomiese regte op te eis eerder as om op jou verantwoordelikheid en roeping te konsentreer. 


\subsubsection{Gegewens uit die Nuwe Testament}

\subsubsection{Christus en sosio-ekonomiese regte in die vier Evangelies}

Jesus verkondig die koninkryk van God en die geregtigheid daarvan. Volgens Haughey (1977:276) is die hooftema van die Bergrede

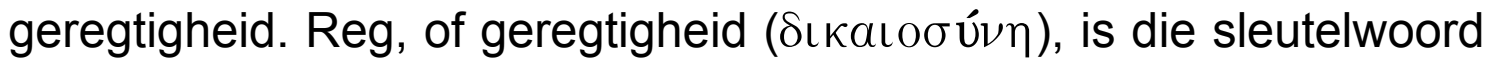
wat deur Matteus gebruik word en is die belangrikste eienskap van God se nuwe orde. Geregtigheid dui op die uniekheid van die koninkryk wat Jesus verkondig. Net 'n paar verwysings uit Matteus is nodig om hierdie feit te beklemtoon (Matt. 5:6, 10, 20; 6:33):

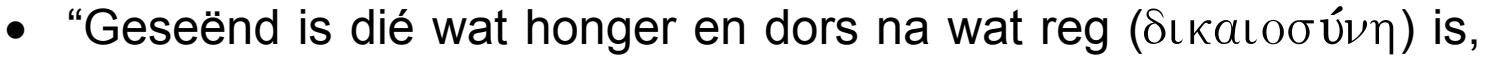
want hulle sal versadig word."

- "Geseënd is dié wat vervolg word omdat hulle doen wat reg $\delta\llcorner\kappa a\llcorner о \sigma u ́ \nu \eta)$ is, want aan hulle behoort die koninkryk van die hemel."

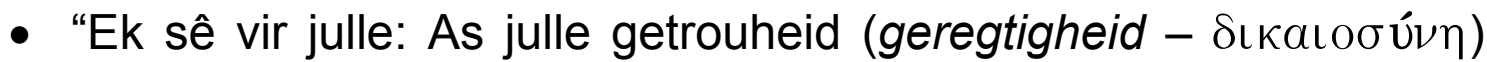
aan die Wet nie meer inhou as dié van die skrifgeleerdes en die Fariseërs nie, sal julle nooit in die koninkryk van die hemel ingaan nie."

- "Nee, beywer julle allereers vir die koninkryk van God en vir die

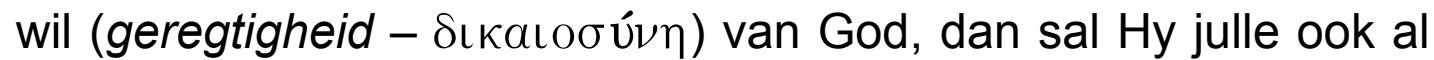
hierdie dinge gee."

Jesus het egter nie net geregtigheid verkondig nie, maar ook deur sy optrede het Hy geregtigheid laat geskied. Spesifiek op sosioekonomiese gebied het Hy geregtigheid laat geskied (vgl. Matt. 9:912; Matt. 14:13-21; Mark. 6:30-44; Matt. 22:37-39; Mark. 2:13-17; Luk. 5:27-32; Luk. 8:1-3; Luk. 9:10-17; Luk. 16:19-31; Joh. 6:1-14; Joh. 11:17-32; e.a.). Hierin het Hy die volmaakte voorbeeld gestel van hoe mense geregtigheid ook op sosio-ekonomiese gebied moet laat geld.

\subsubsection{Die boek Handelinge}

Heel aan die begin van die boek Handelinge word beskryf hoe die Jerusalemgemeente deur die werking van die Heilige Gees in mekaar se behoeftes voorsien het deur selfs hulle besittings te verkoop. Die gemeente het mekaar se sosiale en ekonomiese regte erken. God verander mense se harte so dat hulle ander op die hande begin dra (Hand. 2:42-47). Op hierdie manier is hierdie 
gemeente 'n voorbeeld teenoor die wêreld oor hoe God wil hê dat mense mekaar se sosio-ekonomiese regte moet erken.

Later in die boek Handelinge ken Petrus se verwondering oor God se dade geen perke nie (Hand. 10:38-43). God trek die Jode nie voor nie, maar behandel alle mense gelyk. Enigeen wat God vereer (letterlik "vrees") en doen wat reg is in sy oë, geniet die guns van God - al is hy, soos Kornelius, nie 'n Jood nie. Dit beteken egter nie dat 'n mens deur die doen van hierdie twee dinge die saligheid verwerf nie - vergifnis van sondes bly nodig (vgl. Hand. 10:43).

Wanneer Paulus afskeid neem van die ouderlinge van Efese, dan sê hy vir hulle in Handelinge 20:35:

Deur my voorbeeld het ek in elke opsig vir julle gewys dat ons hard moet werk sodat ons die armes kan help. Onthou die woorde van die Here Jesus. Hy het self gesê: Om te gee, maak 'n mens gelukkiger as om te ontvang.

Die Griekse woord wat vir "armes" gebruik word, is $\dot{\alpha} \theta \in \nu$ oú $\nu T \omega \nu$. Dié woord kan egter ook vertaal word met "swakke" of "diegene wat in nood is" (Stählin, 1976:491). Paulus het 'n voorbeeld gestel deur in die sosiale en ekonomiese behoeftes te voorsien van dié wat in nood is.

\subsubsection{Ander geskrifte in die Nuwe Testament}

In die Nuwe Testament, met die verkondiging van die koninkryk van God aan alle nasies, verklaar Paulus die volgende: "Dit maak nie saak of iemand Jood of Griek, slaaf of vry, man of vrou is nie: in Christus Jesus is julle almal één" (Gal. 3:28). En hoewel Paulus die slaaf Onesimus na sy meester Filemon terugstuur, stuur hy hom terug "nie langer net as 'n slaaf nie, maar meer as 'n slaaf: as 'n geliefde broer" (Filem. 16). Hierdie hoë siening van menslike lewe is in ooreenstemming met Jesus se selfidentifisering met die taak van die koninkryk van God "om die evangelie aan armes te verkondig [...] om vrylating vir gevangenes uit te roep en herstel van gesig vir blindes, om onderdruktes in vryheid uit te stuur, om die genadejaar van die Here aan te kondig" (Luk. 4:18.) In kontras met baie bevrydingsteologieë dui Ridderbos (soos aangehaal deur Greidanus, 1984:17) aan dat die verkondiging van vryheid die volgende behels:

[It] is before all things the liberation of the Kingdom of God, the proclamation of grace - to make man free for God, to restore to 
him the grace and the right to be a child of God, and to set him in the liberty of the children of God.

Die evangelie van die koninkryk van God is 'n boodskap van verlossing en vryheid van menslike lewe. Daarom durf die Kerk nie stilbly wanneer mense in gebondenheid en slawerny (of dit nou geestelik, sosiaal of ekonomies van aard is) verkeer nie - deur hulle eie sondes, deur die sondes van ander mense, deur politieke stelsels, deur 'n materialistiese struktuur van 'n gemeenskap; saamgevat: deur al die sondige en skadelike magte wat die wêreld regeer as gevolg van die werk van Satan en die skuld van die mens.

Die waarde en gehalte van menslike lewe moet nie net deur uiterlike wette beskerm word nie, maar ook deur innerlike gesindheid. Paulus sê in Romeine 13:9, 10 dat al die gebooie in een sin saamgevat kan word: "Jy moet jou naaste liefhê soos jouself. Die liefde doen die naaste geen kwaad aan nie. Daarom is die liefde die volle uitvoering van die wet."

In 1 Korintiërs 9:3-14 argumenteer Paulus vir die reg op lewensonderhoud, die reg om 'n vrou saam te neem en die reg om uit die verkondiging van die evangelie te lewe. In ooreenstemming met Deuteronomeum 25:4 sê Paulus dan in vers 10: "Hy wat ploeg, moet met verwagting ploeg, en hy wat dors, moet dit doen met die verwagting om sy deel te ontvang." Elke mens het dus die reg op regverdige vergoeding.

Dit is reeds duidelik dat 'n regverdige mens besorg is oor die reg van arm mense (Spr. 29:7). 'n Regverdige mens erken nie net die regte van armes nie, maar sal ook probeer om dit te handhaaf (Jak. 2:4-17). Wat die arme dan ontvang, is nie welwillendheid nie, maar geregtigheid. Wanneer Paulus middele bymekaarmaak vir die armes, doen hy dit nie net "om ander te kan help nie; maar sodat daar ewewig sal wees" (2 Kor. 8:13). Alle mense is na die beeld van God gemaak. Daarom het alle mense die gelyke reg op noodsaaklikhede in die lewe soos vryheid en rus, kos en klere, regverdige betaling en geleenthede, sosiale sekuriteit en geregtigheid. Hierdie regte is deur God aan elkeen gegee wat na sy beeld gemaak is, en hierdie regte moet ook in hedendaagse wetgewing beskerm word (Greidanus, 1984:21).

In Openbaring 21:3, 4 gee God 'n heerlike belofte:

Kyk, die woonplek van God is nou by die mense. Hy sal by hulle bly; hulle sal sy volke wees en God self sal by hulle wees as hulle God. Hy sal al die trane van hulle oë afdroog. Die dood 
sal daar nie meer wees nie. Ook leed, smart en pyn sal daar nie meer wees nie. Die dinge van vroeër het verbygegaan.

Eendag sal die stryd vir menseregte verby wees: nie meer dood, leed, smart, pyn en trane nie, maar die volheid van lewe en geregtigheid in God se koninkryk. Intussen lewe gelowiges in die spanning van die "reeds" van die koninkryk en die "nog nie" van die koninkryk, vasgevang in die stryd tussen die koninkryke van die lig en die duisternis, in die stryd om God se geregtigheid ook op die gebied van menseregte te laat geld.

\section{Samevatting en gevolgtrekking}

Uit die bespreking is dit duidelik dat sosio-ekonomiese regte prinsipieel gefundeer kan word en dat die Skrif 'n hoë premie plaas op die beskerming daarvan. Die Bybelse beginsels van geregtigheid, sedelike verantwoordelikheid, liefde, barmhartigheid en arbeid beklemtoon hierdie feit en verskeie gedeeltes in die Ou en Nuwe Testament wys op die belangrikheid van sosio-ekonomiese regte.

'n Belangrike prinsipiële riglyn wat die Skrif dus gee, is dat sosioekonomiese regte so effektief as moontlik deur 'n grondwet beskerm behoort te word. In regskringe is daar tans drie standpunte oor die grondwetlike beskerming van sosio-ekonomiese regte:

- In die eerste plek is daar navorsers, waaronder Didcott (1988:60), wat van mening is dat sosio-ekonomiese regte nie deel kan wees van 'n grondwet nie. Kanada is 'n voorbeeld van 'n land met so 'n grondwet.

- In die tweede plek is daar navorsers, waaronder Davis (1992: 487), wat ten gunste is van sosio-ekonomiese regte in 'n grondwet, maar slegs as rigtinggewende beginsels. Indië is ' $n$ voorbeeld van 'n land met so 'n grondwet.

- In die derde plek is daar navorsers, waaronder De Vos (1997:68), wat ten gunste daarvan is dat sosio-ekonomiese regte as fundamentele regte in 'n grondwet ingesluit word. Suid-Afrika is 'n voorbeeld van 'n land met so 'n grondwet.

Op juridiese gebied is hierdie debat oor die grondwetlike beskerming van sosio-ekonomiese regte nog nie afgehandel nie, maar vanuit die Christelike etiek betoog hierdie artikel vir die effektiewe beskerming van sosio-ekonomiese regte. 


\section{Geraadpleegde bronne}

BOSHOFF, A. 1991. Geregtigheid en sosio-ekonomiese regte in Suid-Afrika. Tydskrif vir Suid-Afrikaanse Reg, 16(3):446-461.

DAVIS, D.M. 1992. The case against the inclusion of socio-economic demands in a bill of rights except as directive principles. South African Journal on Human Rights, 8(3):475-490.

DE BRUYN, P.J. 1993. Die Tien Gebooie. Midrand: Varia.

DE VILLIERS, D.E. 1984. Die geskiedenis van menseregte. (In Du Toit, D.A., red. Menseregte. Kaapstad: Tafelberg. p. 9-39.)

DE VOS, P. 1997. Pious wishes or directly enforceable human rights? Social and economic rights in South-Africa's 1996 Constitution. South African Journal on Human Rights, 13(1):67-101.

DIDCOTT, J.M. 1988. Practical workings of a bill of rights. (In Van der Westhuizen, J. \& Viljoen, H., eds. A bill of rights for South Africa. Durban: Butterworth. p. 52-62.)

DU TOIT, D.A. 1984. Teologie, kerk en menseregte. (In Du Toit, D.A., red. Menseregte. Kaapstad: Tafelberg. p. 60-67.)

DU TOIT, D.A. 1988. Die mens en sy regte. Geloof en praktyk in Suid-Afrika. Kaapstad: Zebra.

DU TOIT, D.A. 1991. 'n Christelik beskouing van menseregte. In die Skriflig, 25(4):439-456.

GREIDANUS, S. 1984. Human rights in biblical perspective. Calvin Theological Journal,19:15-31.

HARRIS, R.L. 1999. Theological wordbook of the Old Testament. Chicago: Moody.

HAUGHEY, J.C. 1977. The faith that does justice: examining the Christian sources for social change. New York: Paulist.

HELBERG, J.L. 1984. Die Ou Testament oor menseregte. In die Skriflig, 18(72):4-12.

HEYNS, J.A. 1982. Teologiese etiek. Pretoria: N.G. Kerkboekhandel.

LIEBENBERG, S. 1995. The International Covenant on economic, social and cultural rights and its implications for South Africa. South African Journal on Human Rights, 11(3):359-378.

SELEOANE, M. 2001. Socio-economic rights in the South African Constitution. http://www.hsrcpublishers.co.za/index.html/socioecon_rights.html March 2003].

STÄHLIN, G. 1976. $\alpha \sigma \theta \varepsilon v n ́ \varsigma, ~ \alpha \sigma \theta \varepsilon ́ v \varepsilon ı \alpha, \alpha \sigma \theta \varepsilon v \varepsilon ́ \omega$ (In Kittel, G., ed. Theological dictionary of the New Testament. Volume 1. Translated and edited by Geoffrey W. Bromiley. Grand Rapids: Eerdmans. p. 490-493.)

UN

kyk UNITED NATIONS

UNITED NATIONS. 1995. The United Nations and human rights: 1945-1995. New York: United Nations Department of Public Information.

VAN WYK, J.A. 1988. 'n Christelike etiek van die arbeid. Pretoria: NG Kerkboekhandel.

VAN WYK, J.H. 1987. Etiek en menseregte. In die Skriflig, 21(81):31-40.

VAN WYK, J.H. 1991. Moraliteit en verantwoordelikheid. Opstelle oor politieke etiek. Potchefstroom: $\mathrm{PU}$ vir $\mathrm{CHO}$.

VAN WYK, J.H. 2001. Etiek en eksistensie in koninkryksperspektief. Potchefstroom: Potchefstroomse Teologiese Publikasies. 
VON RAD, G. 1962. Old Testament theology. Vol. 1. Edinburgh: Oliver \& Boyd. VORSTER, J.M. 2000. The emergence of the ethos of human rights. Studia Historiae Ecclesiasticae, 26(2):116-141.

VORSTER, J.M. 2001. 'n Christelike teorie van menseregte. In die Skriflig, 35(1):1-22.

VORSTER, N. 2002. Kerk en menseregte binne 'n regstaat: die profetiese roeping van die kerk ten opsigte van die vestiging van 'n etos van menseregte in Suid-Afrika. Potchefstroom: PU vir CHO. (Th.D.-proefskrif.)

\section{Kernbegrippe:}

sosio-ekonomiese regte

Suid-Afrikaanse Grondwet: beskerming van fundamentele regte teologies-etiese beoordeling van menseregte

\section{Key concepts:}

socio-economic rights

South African Constitution: safeguarding of fundamental rights theological-ethical evaluation of human rights 